\title{
A MECHANISM ANALYSIS OF TRANSVERSE WELD CRACKS OF MARINE THICK STEEL PLATE
}

\author{
Haibo Wang, Dongpo Wang, Fangjie Cheng, Ying Wang
}

Original scientific paper

In the welding process of jackets for offshore platform, transverse weld cracks occur frequently, even when welding techniques, welding materials and marine steel plates used are stringently selected. But now defect failure analysis and mechanism study on this issue are scarce. To fully study the causes of transverse weld cracks of marine thick steel plate, this research uses instruments including metalloscope, scanning electron microscope (SEM), Energy Dispersive Spectrometer (EDS) and Auger Electronic Spectrom (AES). Researchers conclude that transverse weld cracks are welding hot cracks.

Keywords: inclusions; thick steel plate; transverse weld cracks; welding hot crack

\section{Analiza mehanizma poprečnih lomova zavara brodskog debelog čeličnog lima}

Izvorni znanstveni članak

U postupku zavarivanja omotača za offshore platforme, često dolazi do poprečnih lomova zavara, čak i kada su tehnike zavarivanja, materijali za zavarivanje i brodski čelični limovi pomno odabirani. Sada, međutim, postoji mali broj istraživanja i analiza uzroka takvih oštećenja. U svrhu cjelovite analize uzroka poprečnih lomova zavara brodskog debelog čeličnog lima, ovo istraživanje koristi instrumente kao što su metaloskop, skenirajući elektronski mikroskop (SEM), energo disperzivni spektrometar (EDS) i auger elektronički spektrometar (AES). Zaključak je istraživača da su poprečni lomovi zavara lomovi zbog topline zavarivanja.

Ključne riječi: inkluzije; debeli čelični lim; lomovi zbog topline zavarivanja; poprječni lomovi zavara

\section{Introduction}

With the development of shipbuilding industry and offshore oil industry, more large marine steel structures are needed. High-strength ship plate steel has been given certification by the Classification Society and is used in making large vessels and offshore oil drilling platform, among other things. But in the process of building offshore platform, although steel plates are qualified in reinspection and welding work is done according to welding specifications of the project and AWS specifications, many transverse weld cracks occur frequently. Weld crack is a common defect and one of the most dangerous defects. Cracks can be divided into hot cracks and cold cracks. Hot cracks occur in the process of welding solidification. Eutectic material with low melting point accumulates in the grain boundary and forms a liquid film. As weld line solidifies and shrinks, the liquid film is subject to tensile stress and cracks.

Hot crack is also called crystal crack. It often cracks along the longitudinal direction of the crack. Sometimes the crack occurs between two columnar crystals inside the weld line, along the horizontal direction of the weld line and is called transverse crack. Cold cracks usually occur after the weld line cools and is under the Martensitic transformation temperature, and thus it is also called delayed crack. Restraint stress, hardening organization and diffusible hydrogen are three causes of the formation of cold cracks $[1,2]$. Up to now, H. W. Lee and others have conducted studies on formation of transverse weld cracks, researching on the relationship between transverse cold cracks and restraint stress [3] and welding technique $[4,5]$ in welding of marine medium and thick steel plate. They finally came to the conclusion that transverse weld cracks are hydrogen-induced cold cracks [6] and proposed the corresponding welding procedures. But at present, transverse weld cracks still occur very frequently in making marine engineering structures and there are few studies on failure cases of transverse cracks. This study conducts comprehensive analysis of several cases of transverse cracks in actual engineering structures and concludes that the occurrence of transverse cracks is closely related with inclusions and heat treatment of base metal.

\section{Testing and analysis}

In the process of making welded rods of large thickness and large diameter for offshore oil platform, some defects are detected by ultrasonic wave in rods welded of $30 \mathrm{~mm}$ steel plates and are suspected transverse weld cracks. Such rods are made of DH36 (ASTM A131) ship steel plates, which are qualified in reinspection. The plate is rolled into a cylinder with a diameter of $1,6 \mathrm{~m}$ and a length of $3 \mathrm{~m}$ and is welded with the technique of submerged arc welding (SAW). Then girth weld is done to connect rods using JW-1 welding wire and JF-B flux. Cracks mainly occur in longitudinal joints and $50 \%$ of rods have cracks and one rod has several cracks. There are also same defects in girth welds.

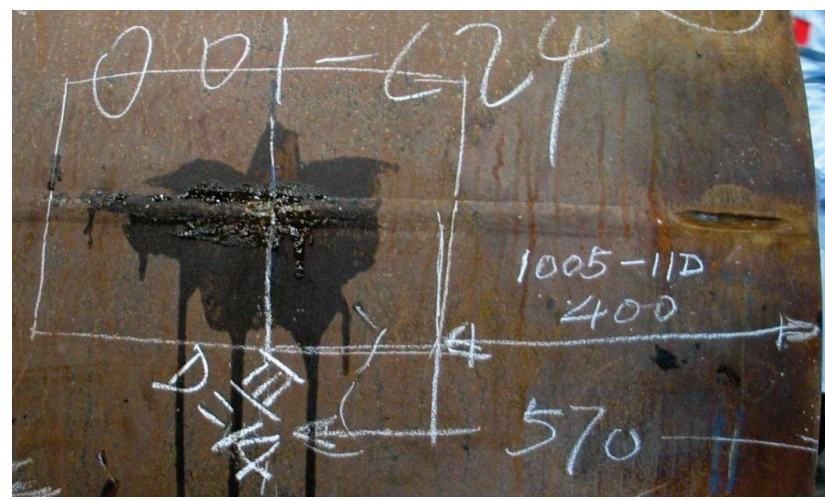

Figure 1 Rods with transverse cracks detected by ultrasonic test 


\subsection{Location determination of micro-cracks}

First, along the direction of the welding line, at 15 $\mathrm{mm}$ from the two weld toes cut the sample plate into three pieces and keep the one with welding line. Mill the upper side of the steel bar with welding line off $8 \mathrm{~mm}$ and the lower side off $5 \mathrm{~mm}$ and reserve the middle layer, which is about $19 \mathrm{~mm}$ thick. Cut the middle bar at the middle of welding line into two parts along the welding line direction. Mark the middle of welding line of the left part as coordinate zero point and use WEDM to cut the bar at $5 \mathrm{~mm}$ and $10 \mathrm{~mm}$ (See Fig. 2, the two parts are marked as 4\#, 5\#, 6\# samples). No cracks are detected after 4\# and $5 \#$ samples are polished and colored for inspection. The left part is divided into four parts by cutting at $3 \mathrm{~mm}$, $6 \mathrm{~mm}$ and $9 \mathrm{~mm}$ from the middle of welding line (See Fig. 2 , they are marked as $1 \#, 2 \#, 3 \#, 7 \#$ samples). After being polished and dye penetrant inspection for inspection, two cracks are found in $2 \#$ and $3 \#$ samples, whose longitudinal coordinate positions are $X=127 \mathrm{~mm}$ and $X=292 \mathrm{~mm}$, which are in line with the ultrasonic flaw detection results (Fig. 3).
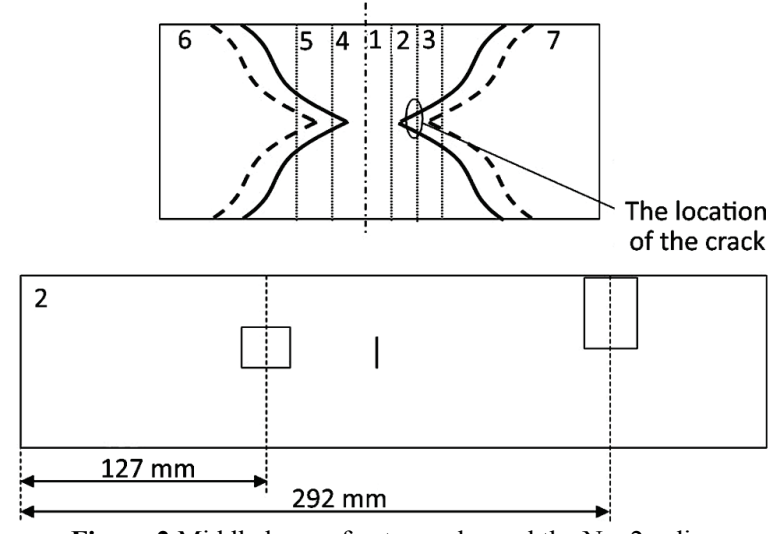

Figure 2 Middle layer of cut samples and the No. 2 spline
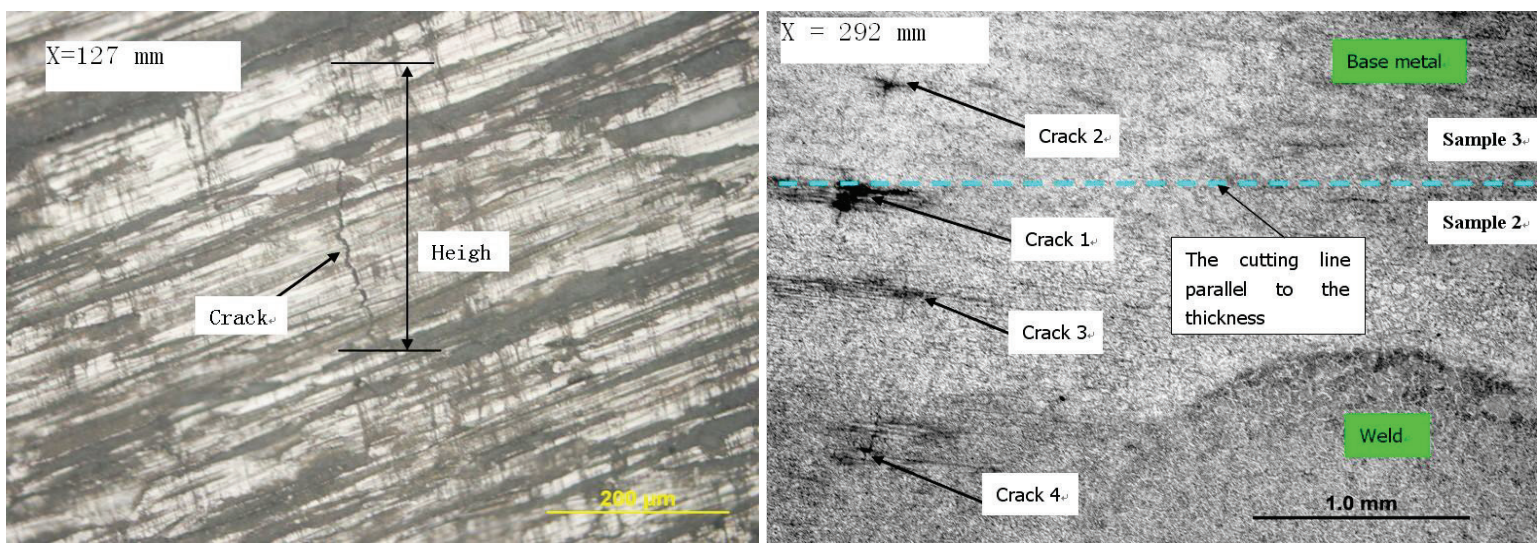

Figure 3 Photos of cracks detected at $X=127 \mathrm{~mm}$ and $X=292 \mathrm{~mm}$

\subsection{Metallographic analysis}

The sample is observed through digital metalloscope (OLYMPUSGX51) at $X=292 \mathrm{~mm}$ and four cracks are found with height of $0,2 \div 0,3 \mathrm{~mm}$ and all of them are in the heat-affected zone (HAZ). To decide on the location of the crack, the researcher chose crack 1 and used polishing machine to grind it slightly for many times until the crack can be observed under microscope. Then it is made into metallographic sample for observation. The researcher checks whether all the length of the crack is in the HAZ, observes the direction of the crack and whether there are inclusions between cracks.

Just as shown in Fig. 4, the crack is all in the HAZ along its longitudinal direction. Several transverse cracks are discovered on this section. Cracks often start from the pearlite strip of incompletely banded structures. There are also cracks parallel to the thickness direction, crossing transverse cracks.
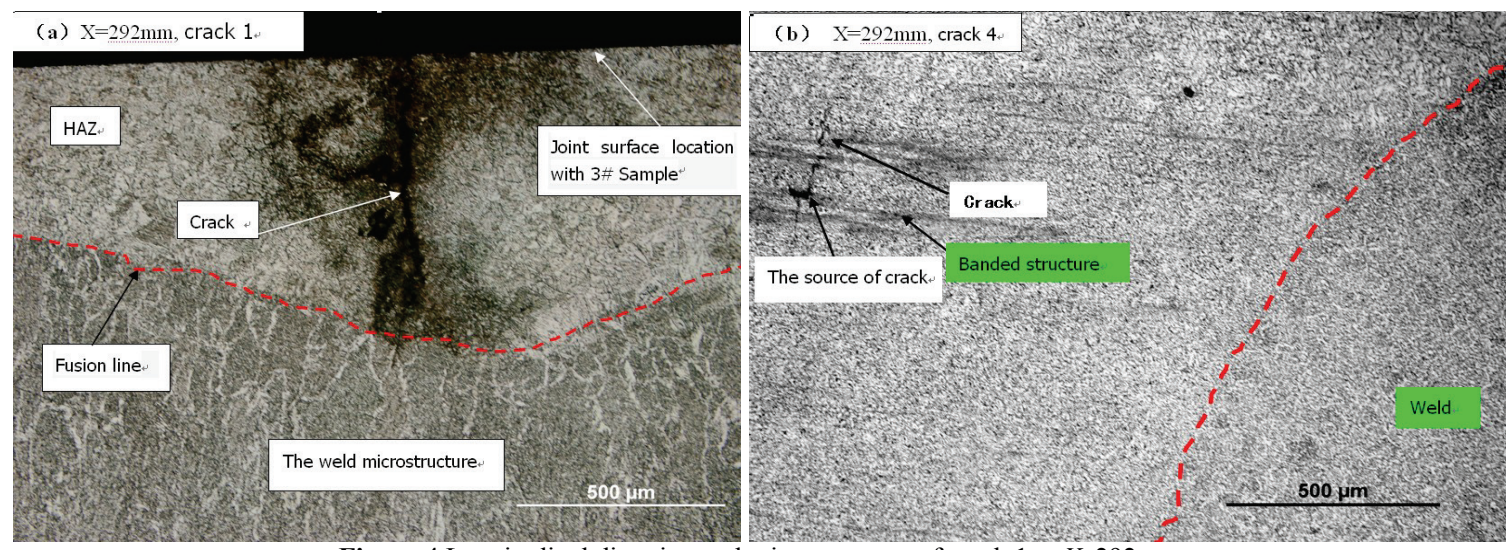

Figure 4 Longitudinal direction and microstructure of crack 1 at $X=292 \mathrm{~mm}$

From Fig. 5 we can see that along the crack's thickness direction, it is also in the HAZ of the base steel.
Several inclusions are discovered in the cracks and there is an obvious incompletely banded structure. These minor 
cracks all start from the pearlite strip of incompletely banded structures. There are also cracks parallel to the thickness direction, crossing transverse cracks. Therefore, we have reasons to doubt whether the occurrence of cracks is related with the banded structure.
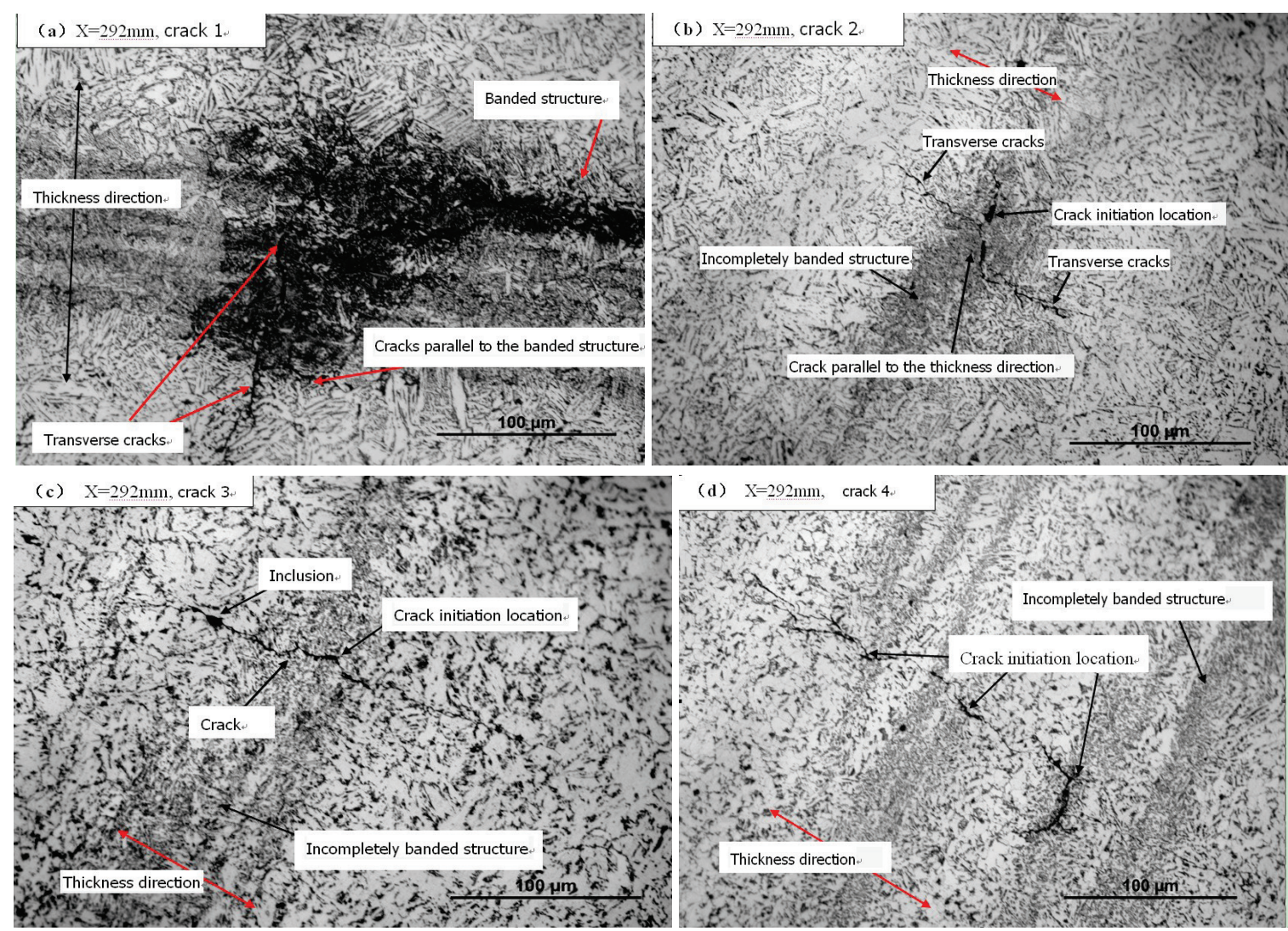

(d) $\mathrm{X}=292 \mathrm{~mm}$, crack 4

Figure 5 Thickness direction and microstructure of crack 1 at $X=292 \mathrm{~mm}$

From a-h of Fig. 6, we can see that cracks are closely related to inclusions and banded structures. The severity of banded structure is closely related to dendrite segregation of alloying elements such as Mn, Si, S and P. There are serious banded structures in the microstructure of the $30 \mathrm{~mm}$ base metal, so regional segregation and segregation in grain boundary pearlite strip of $\mathrm{S}$ and $\mathrm{P}$ is also serious. Therefore, although $\mathrm{S}$ and $\mathrm{P}$ content of the steel is very low, low melting point eutectic film of high density of $\mathrm{S}$ and $\mathrm{P}$ is formed in pearlite bands. In the welding process, this area is heated and liquefied and under the longitudinal welded strain transverse liquefied cracks occur in the HAZ. Therefore, segregation of elements of low melting point eutectic impurities (formed in the continuous casting and rolling of steel) in dendrite boundaries is the root cause of the liquefied transverse cracks in the HAZ. The occurrence of banded structure just reflects the serious segregation of impurity elements in the dendrite boundary. Of course, wide HAZ and big longitudinal weld shrinkage strain caused by the welding technique SAW, which has high linear energy, are also important reasons.

\subsection{Fracture analysis}

To analyze the mechanism of the occurrence of cracks, sample $2 \#$ having cracks in the surface is fractured at $X=127 \mathrm{~mm}$ (shown in Fig. 1) under cooling conditions of liquid nitrogen. Its fracture is being observed by SEM and AES to conduct morphology and tissue analysis.

Morphology observation is done by SEM (SUPRA 55VP) (See Fig. 7). We can see that the fracture is smooth, which is a typical feature of hot cracks starting from Austenite grain boundaries, not the feature of cold cracks. To further determine the occurrence mechanism of cracks, we need to conduct chemical analysis of the crack surface to see whether there is low-melting-point eutectic composition of elements such as $\mathrm{S}$ and $\mathrm{P}$ which give rise to hot cracks, whether there is segregation of elements of low melting point such as $\mathrm{Pb}$ and whether there is enrichment of $\mathrm{Si}, \mathrm{Mn}$ and other elements that can form grain boundary inclusions. First researchers do EDS analysis under FESEM (field emission scanning electron microscope). EDS chemical analysis of the crack (Fig. 8) shows that chemical composition of this area has no significant difference with non-crack area of the fracture and no signs of segregation of S, P, Si and other elements are discovered. As EDS detects the average composition within several micron under the surface, so it cannot accurately reflect the chemical composition of the crack. Segregation layer can be as thin as several nm, so EDS alone cannot exclude the possibility of segregation. Therefore, we need to conduct AES analysis. 

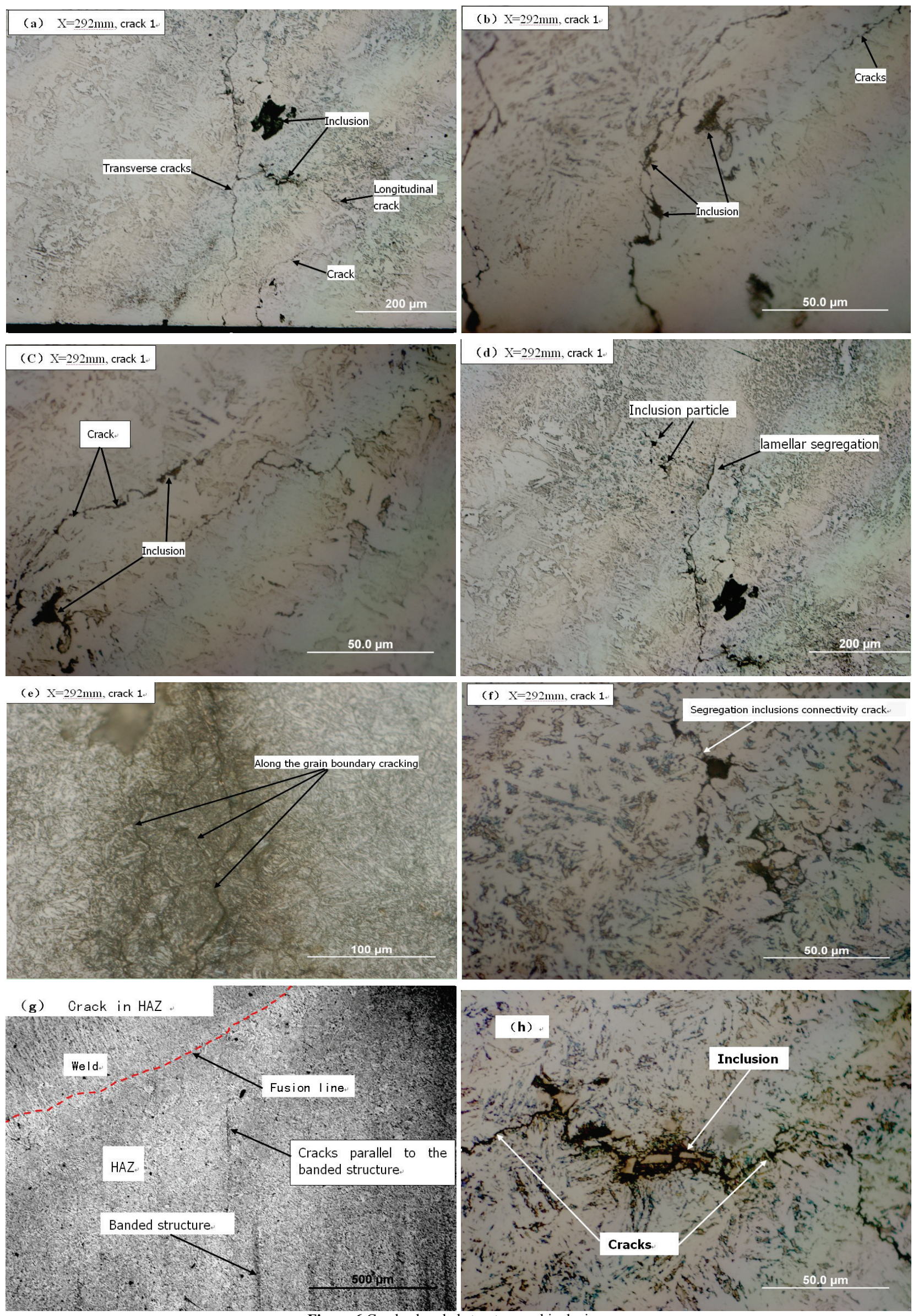

Figure 6 Cracks, banded structure and inclusions 


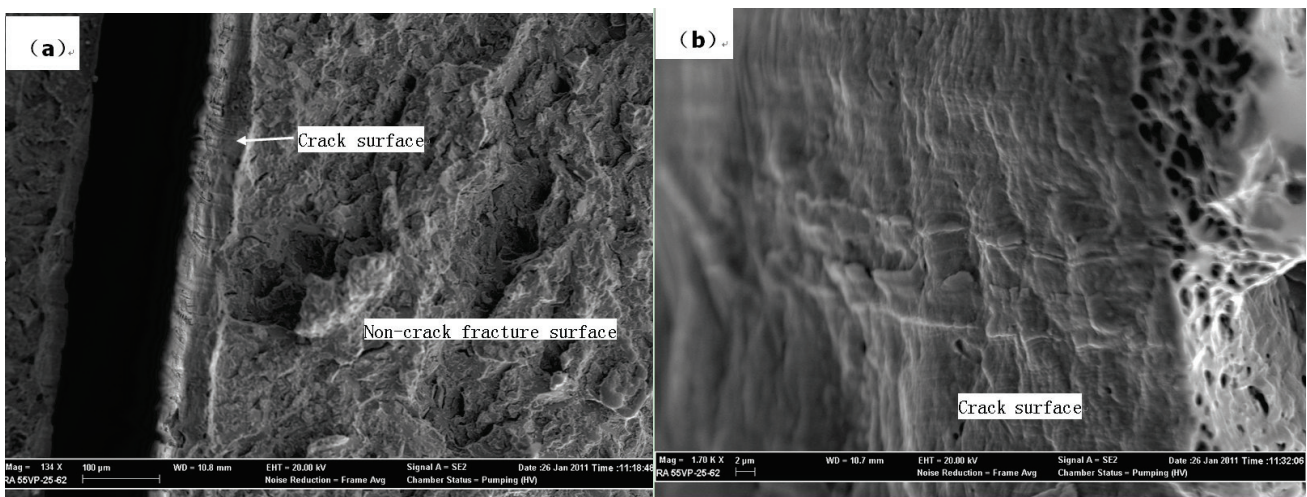

Figure 7 SEM photo of transverse crack at $X=127 \mathrm{~mm}$

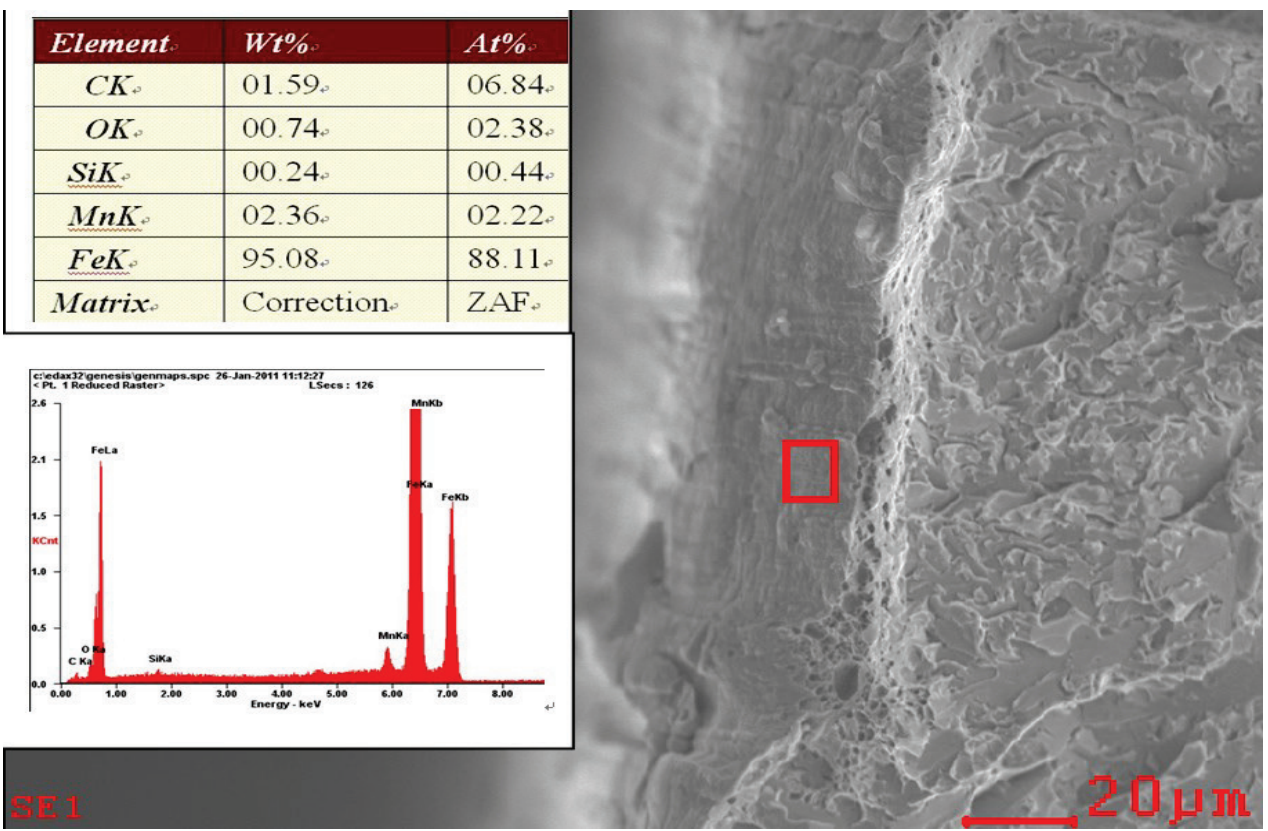

Figure 8 EDS chemical analysis of crack

\subsection{AES analysis}

As EDS analysis failed to discover segregation of elements, the researcher uses AES (Perkin PHI670) to determine chemical composition of the crack. It needs to be mentioned that Auger electron spectroscopy shows the percentage of numbers of atoms, not that of quality of atoms. As the sample is easy to be contaminated by elements such as $\mathrm{C}$ and $\mathrm{O}$, so Argon gas is used to do bombardment cleaning on the fracture surface to remove some contaminants. However, most $\mathrm{C}$ and $\mathrm{O}$ contaminants cannot be effectively removed, so the analysis of testing result should take into account the influence of contaminants. Four locations of the crack surface are chosen for the test (shown in Figs. $9 \div 12$ ). One location of non-crack surface is chosen and tested (Fig. 13).

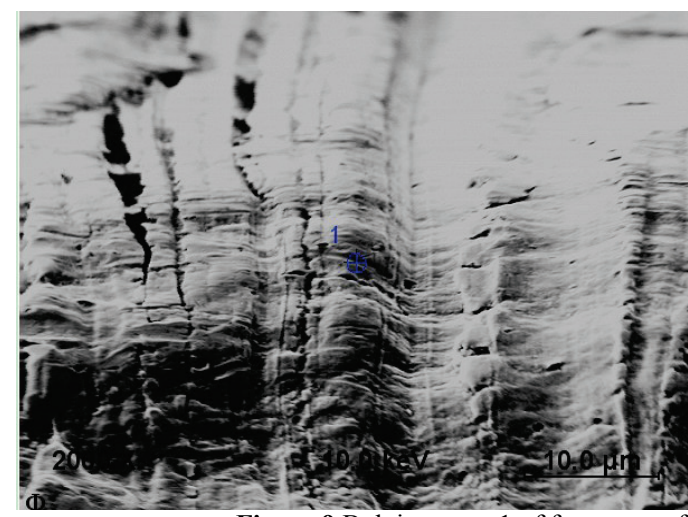

Figure 9 Bulging zone 1 of fracture surface, AES analysis and the spectrum curve

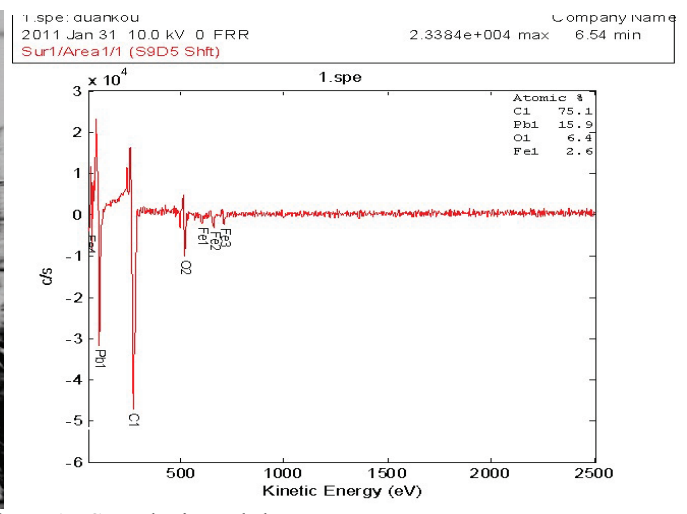

the AES spectrum indicate that apart from some $\mathrm{C}$ and $\mathrm{O}$, which are contaminants, the main chemical composition 
is $\mathrm{Pb}$ and $\mathrm{Fe}$. As there is very low level of $\mathrm{Pb}$ in the noncrack area of the fracture surface, that shows $\mathrm{Pb}$, as an inclusion, is likely to have severe segregation in some areas. The melting point of $\mathrm{Pb}$ is as low as $328^{\circ} \mathrm{C}$ [7], and these areas are in the grain boundary of the HAZ. The existence of $\mathrm{Pb}$ is likely to facilitate the occurrence of liquefied cracks.
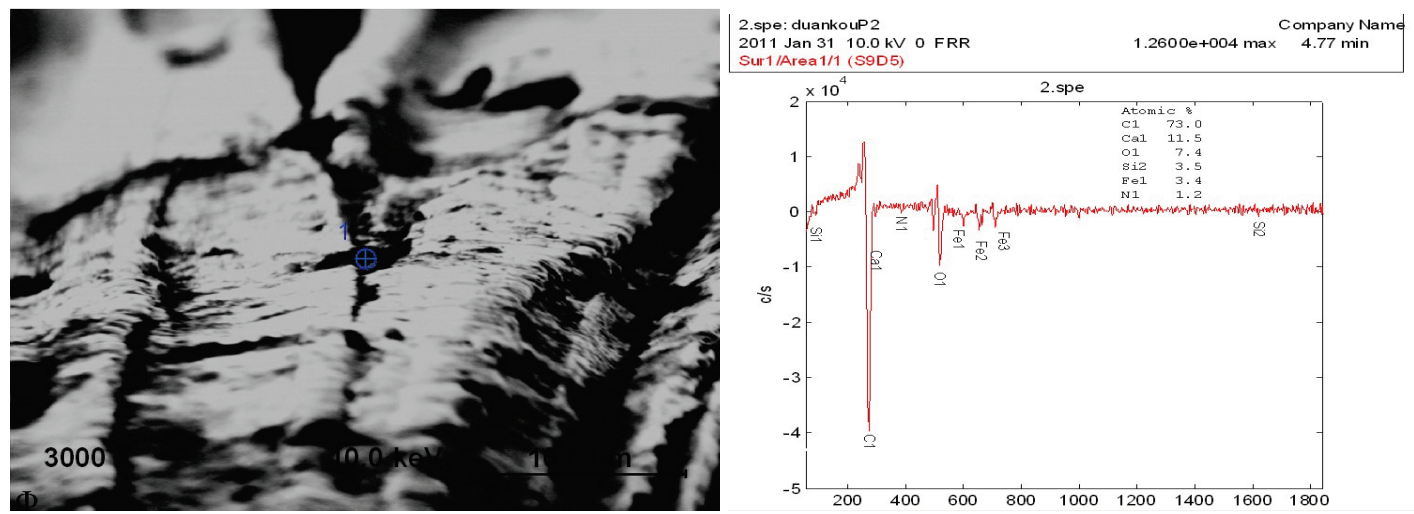

Figure 10 Recessed zone of fracture surface, AES analysis and the spectrum curve
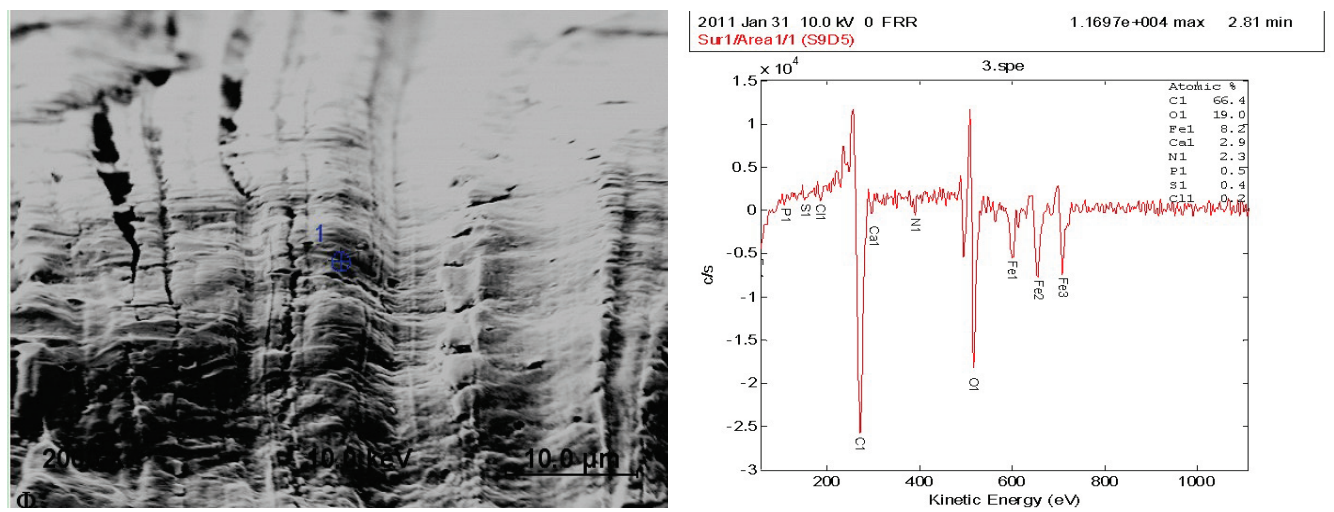

Figure 11Bulging zone 2 of fracture surface, AES analysis and the spectrum curve
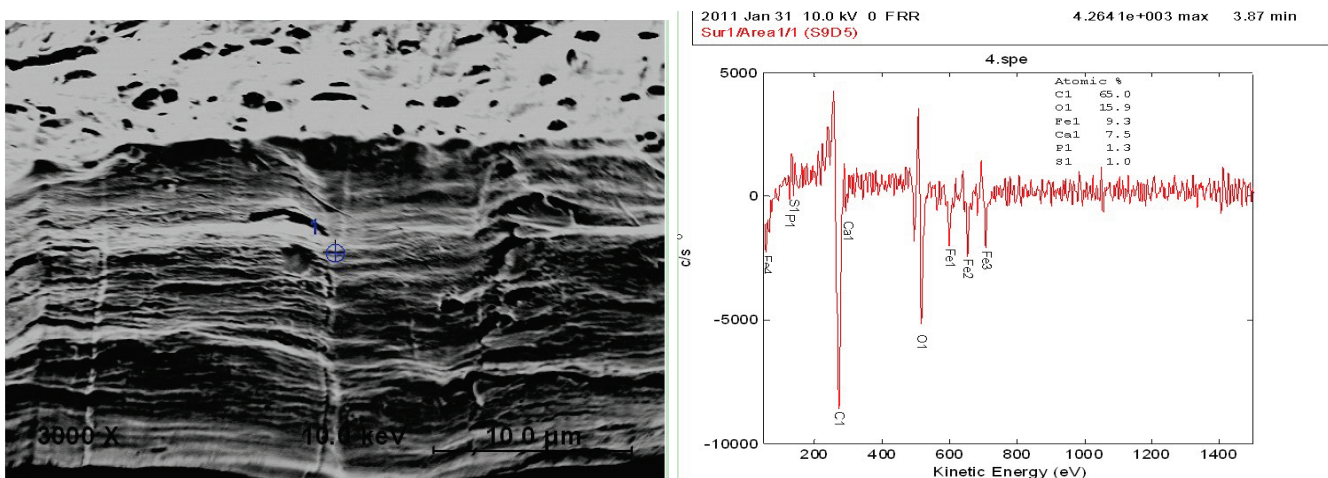

Figure 12 Grain boundary junction of fracture surface AES analysis and the spectrum curve
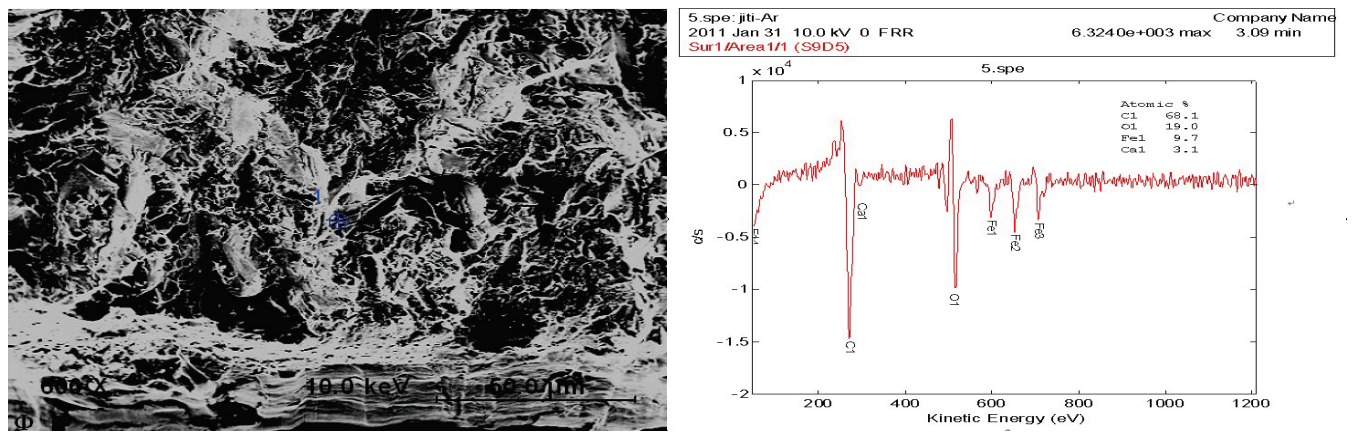

Figure 13 Non-crack area of fracture surface, AES analysis and the spectrum curve

Chemical analysis (counted in numbers of atoms) of recessed zone of fracture surface (shown in Fig. 10) and the AES spectrum indicate that apart from some $\mathrm{C}$ and $\mathrm{O}$, which are contaminants, the main chemical composition is $\mathrm{Si}, \mathrm{Ca}$ and $\mathrm{Fe}$. As there is very low level of $\mathrm{Si}$ in the non-crack area of the fracture surface that shows $\mathrm{Si}$ is 
likely to have severe segregation in some areas. It is also possible that $\mathrm{Si}$ exists as $\mathrm{SiO}_{2}$ inclusions.

Chemical analysis of bulging zone 2 of fracture surface (shown in Fig. 11) and the AES spectrum indicate that apart from some $\mathrm{C}$ and $\mathrm{O}$, which are contaminants, the main chemical composition is $\mathrm{Fe}, \mathrm{S}, \mathrm{P}$ and $\mathrm{Ca}$. As there is very low level of $\mathrm{S}$ and $\mathrm{P}$ in the non-crack area of the fracture surface, that shows $\mathrm{S}$ and $\mathrm{P}$ are likely to have severe segregation in some areas. According to the proportion of elements, eutectic materials of low melting point such as $\mathrm{Fe}-\mathrm{FeS}$ and $\mathrm{Fe}-\mathrm{Fe}_{3} \mathrm{P}$ may be formed, the melting point of $\mathrm{Fe}-\mathrm{FeS}$ is $998^{\circ} \mathrm{C}$ [7]; the melting point of $\mathrm{Fe}-\mathrm{Fe} 3 \mathrm{P}$ is $1040^{\circ} \mathrm{C}[7]$. The existence of such matters is likely to be one major reason for the occurrence of liquefied cracks.

Chemical analysis of the grain boundary junction of fracture surface (shown in Figure 12) and the AES spectrum indicate that apart from some $\mathrm{C}$ and $\mathrm{O}$, which are contaminants, the main chemical composition is $\mathrm{Fe}, \mathrm{S}$ and $\mathrm{P}$, and the content of $\mathrm{S}$ and $\mathrm{P}$ is more than twice that of fracture surface. As there is very low level of S and $\mathrm{P}$ in the non-crack area of the fracture surface that shows the segregation of $\mathrm{S}$ and $\mathrm{P}$ is likely to be severer in this area than bulging zone 2 . It is likely that there is a large amount of eutectic materials of low melting point such as $\mathrm{Fe}-\mathrm{FeS}$ and $\mathrm{Fe}-\mathrm{Fe}_{3} \mathrm{P}$.

Chemical analysis of the Non-crack area of fracture surface (shown in Figure 13) and the AES spectrum indicate that apart from some $\mathrm{C}$ and $\mathrm{O}$, which are contaminants, the main chemical composition is $\mathrm{Fe}$, and elements such as $\mathrm{S}, \mathrm{P}, \mathrm{Ca}, \mathrm{Si}$ and $\mathrm{Pb}$ are not displayed because their contents are too small.

In short, according to AES analysis results (Tab. 1), there is $\mathrm{Pb}$, melting point of which is low, segregation of $\mathrm{S}$ and $\mathrm{P}$ on the fracture surface, which can lead to lowmelting-point eutectic materials such as Fe-FeS and Fe$\mathrm{Fe}_{3} \mathrm{P}$. Moreover, there is also segregation of $\mathrm{Si}, \mathrm{O}$ and $\mathrm{Ca}$ on the crack surface, which can lead to inclusions such as $\mathrm{SiO}_{2}-\mathrm{CaO}$.

Table1 AES analysis results of all areas / \% Atomic
\begin{tabular}{|l|c|c|c|c|c|c|c|c|c|}
\hline & $\mathrm{C}$ & $\mathrm{Si}$ & $\mathrm{Ca}$ & $\mathrm{S}$ & $\mathrm{P}$ & $\mathrm{Pb}$ & $\mathrm{O}$ & $\mathrm{Fe}$ & $\mathrm{N}$ \\
\hline Bulging zone 1 of fracture surface & 75,1 & - & - & - & - & 15,9 & 6,4 & 2,6 & - \\
\hline Recessed zone of fracture surface & 73,0 & 3,5 & 11,5 & - & - & - & 7,4 & 3,4 & 1,2 \\
\hline Bulging zone 2 of fracture surface & 66,4 & - & 2,9 & 0,4 & 0,5 & - & 19,0 & 8,2 & 2,3 \\
\hline Grain boundary junction & 65,0 & - & 7,5 & 1,0 & 1,3 & - & 15,9 & 9,3 & - \\
\hline Base metal & 68,1 & - & 3,1 & - & - & - & 19,0 & 9,7 & - \\
\hline
\end{tabular}

\section{Conclusion}

The analysis of location and direction of cracks shows that the cracks are in the HAZ, whether in longitudinal direction of thickness direction, which indicates that these transverse cracks are HAZ weld cracks. The observation of crack surface at $X=127 \mathrm{~mm}$ through SEM shows that the surface is smooth, which is a typical feature of cracks starting from Austenite grain boundaries. This is a feature of hot cracks, not cold cracks.

EDS analysis of several areas of crack surface fails to discover obvious segregation of chemical elements. Considering it is because the low-melting-point liquid film is too thin and EDS spectrum reaches too deep, so the researcher adopts AES to analyze the same surface. As a result, segregation of $\mathrm{Pb}, \mathrm{S}$ and $\mathrm{P}$ is discovered. $\mathrm{S}$ and $\mathrm{P}$ will lead to eutectic materials with low melting point such as $\mathrm{Fe}-\mathrm{FeS}$ and $\mathrm{Fe}-\mathrm{Fe}_{3} \mathrm{P} ; \mathrm{Pb}$ of low melting point can exist in simple substance or dioxide: These all indicate that such cracks are likely to be liquefied cracks in the HAZ.

The contradiction between results of EDS and AES precisely shows that: Although average content of impurities such as $\mathrm{S}$ and $\mathrm{P}$ is very low, segregation of $\mathrm{Pb}$, $\mathrm{S}$ and $\mathrm{P}$ takes place in extremely thin grain boundary layer. Low-melting-point materials formed by the enrichment of these impurities are heated by the welding process and then give rise to extremely thin liquid film in Austenite grain boundaries, which have enriched impurities of low melting point. Shrinkage strains take place along longitudinal and horizontal direction of the weld line in the cooling process. The strains are perpendicular to the liquid film in the Austenite grain boundary. The strains focus on the liquid film and lead to transverse liquefied cracks.

To confirm this conclusion, the researcher adopts EDS to analyze a section of crack along the thickness direction. The cracks show features of intergranular fracture; serious segregation of $\mathrm{Na}, \mathrm{Mg}, \mathrm{Zn}, \mathrm{Al}, \mathrm{Si}, \mathrm{S}$, Ti, $\mathrm{Ni}, \mathrm{Mn}$ and $\mathrm{Pb}$, which lead to formation of low-meltingpoint eutectic compounds such as $\mathrm{Fe}-\mathrm{FeS}$ and $\mathrm{Fe}_{-} \mathrm{Fe}_{3} \mathrm{P}$. That is line with the testing result of AES of the crack surface.

The EDS analysis also indicates a large amount of niobium alloys containing titanium boride, manganese sulfide, sulfide ferrous oxide, silica, alumina, carbon niobium boride; magnesium and zinc inclusions exist in cracks and neighbouring areas. The inclusions with high melting point in Austenite grain boundary weaken the bonding strength between strains and contribute to the occurrence of hot cracks. Therefore, we conclude that inclusions facilitate the occurring and expanding of cracks but their influence is secondary; eutectic compounds such as $\mathrm{Fe}-\mathrm{FeS} / \mathrm{Fe}-\mathrm{Fe}_{3} \mathrm{P}$ play the major role. The cracks are in the HAZ and the liquid film on their fracture surfaces is smooth; $\mathrm{Pb}$ of low melting point, which is discovered by AES analysis and $\mathrm{S}$ and $\mathrm{P}$, which can lead to eutectic materials, and elements that can form inclusions including $\mathrm{O}, \mathrm{Si}$ and $\mathrm{Ca}$. Considering the cracks are of small size and belong to typical micro cracks, the researchers conclude that such cracks are near-weld-line liquefied cracks, which is a type of hot crack. The mechanisms of such cracks are liquefied cracks in the HAZ.

\section{Abbreviations}

AES - Auger Electron Spectroscopy 
EDS - Energy Dispersive Spectrometer

HAZ - Heat Affected Zone

SEM - Scanning Electron Microscope

WEDM - Wire Cut Electrical Discharge Machining

\section{References}

[1] Kou, S. Welding Metallurgy, $2^{\text {nd }}$ ed., John Wiley and Sons, New York, 2003.

[2] Welding Handbook, vol. 1, $8^{\text {th }}$ ed., AWS, Miami, FL, 1987.

[3] Lee, H. W.; Kang, S. W.; Um, D. S. A study on transverse weld cracks in thick steel plate with the FCAW process. // Welding Journal. 77, 12(1998), pp. 503-510.

[4] Lee, H. W.; Kang, S. W. A study on transverse weld cracks in 50-mm-thick steel plate with the SAW process. // Journal of Japan Welding Society. 15, 4(1997), pp. 563-573. DOI: 10.2207/qjjws.15.563

[5] Lee, H. W.; Choe, W. H.; Park, J. U.; Kang, C. Y.; Park, W. $\mathrm{J}$. Weld metal hydrogen assisted cracking in $50 \mathrm{~mm}$ TMCP steel plate with SAW process. // Science and Technology of Welding and Joining. 11, 3(2006), pp. 243-249. DOl: 10.1179/174329306X94327

[6] Lee, H. W. Weld metal hydrogen-assisted cracking in thick steel plate weldments. // Materials Science and Engineering A 445-446, (2007), pp. 328-335. DOl: 10.1016/j.msea.2006.09.046

[7] http://webbook.nist.gov.

\section{Authors' addresses}

Haibo Wang, Senior Engineer

1) School of Materials Science and Engineering,

Tianjin University, Weijin Rd, 92, Nankai, Tianjin 300072, China

2) Tianjin Special Equipment Inspection Institute,

Hangtian Street, Nankai, Tianjin 300192, China

E-mail: wanghaibo@tju.edu.cn

\section{Dongpo Wang, Prof., PhD}

School of Materials Science and Engineering,

Tianjin University, Weijin Rd, 92, Nankai, Tianjin 300072, China

E-mail: wangdp@tju.edu.cn

Fangiie Cheng, Associate professor, PhD, Corresponding Author School of Materials Science and Engineering,

Tianjin University, Weijin Rd, 92, Nankai, Tianjin 300072, China

Email: chfj@tju.edu.cn

\section{Ying Wang, Associate professor, PhD}

School of Materials Science and Engineering,

Tianjin University, Weijin Rd, 92, Nankai, Tianjin 300072, China

E-mail: wangycl@tju.ed 